\title{
Analysis of the origin of soluble COD in Lake Sanaru
}

\author{
Qian $\mathrm{Yu}^{1}$, AyakaOomae ${ }^{1}$, Hiroyuki Futamata $^{1}$ and Satoshi Matsuda ${ }^{1}$ \\ ${ }^{1}$ Faculty of Engineering, Shizuoka University, 3-5-1 Johoku, Naka-ku, Hamamatsu 432-8561 Japan
}

\begin{abstract}
This study intends to investigate the origin of Sol-COD by analyzing the water quality data and the amount of detergent consumption in the Lake Sanaru region,located at Hamamatsu City in Japan. It was found that there is a correlation between the total COD in the lake and the sewer coverage in the upstream region of Lake Sanaru. This fact implies that the water quality of upstream rivers receiving untreated wastewater from homes would greatly affect the water quality of the lake. Since the value of Sol-COD in the rivers is close to that of Lake Sanaru, the main origin of the Sol-COD was supposed to be the organic components in the river water especially those of detergents, because the Sol-CODof detergent didn't decompose completely.Thus, the amount of detergent emitted in the upstreamlakeregion was determined using the public data of the pollution from the sewer system and the national average of detergent consumption. The calculated value of the detergent concentration agreed very well with the one measured in the upstream rivers, meaning that detergents strongly affected water quality in upstream rivers and also the majority of Sol-COD in Lake Sanaru.
\end{abstract}

\section{Introduction}

The Total-COD can be subdivided into several parts according to wastewater characteristic because in many instances very different[1,2].Theclassification of CODhas often been used inthe design of technology forsewage treatment plants $[3,4]$ butnot much in regards to natural bodies of water.We consider that total COD consists of two parts in general:suspended solid COD (SS-COD) and watersoluble COD (Sol-COD). This classification can give us a much clearer conception of water quality variation including seasonal change and the origin of effluents.

Lake Sanaru is located in the western area of Hamamatsu City, Shizuoka Prefecture in Japan.Since 1999, the annual average of Total-COD value reached $12 \mathrm{mg} / \mathrm{L}$ and it was the worst ranking value of national public water quality in Japan from 2001 to 2006. In recent years, along with the continuously increasing sewer coverage area in the lake region, the amount of nutrients in upstream rivers has decreased. Also, the Total-COD value is no longer in the top five for worst public water quality in Japan[5]. We want to clearly define how the Total-COD decreased and use this information as guidance for the governance of other lakes.First and foremost, the origin of pollution in the lake as well as the condition of SS-COD and Sol-COD in the upstream rivers need to be clarified.

Based on Japan's experience of tackling pollution since the 1970s,strict standard setting and financial support for environmental protection have had a more positive effect[6] than in other countries. We can collect a large quantity of data due to strong monitoring
capacities.In this study we focus on sewer systems, population distribution, basin environment, point sourcesand nonpoint sources to discover the primary originof pollution in Lake Sanaru.

\section{Method}

\subsection{Study area}

\subsubsection{Basin environment}

The average water depth of Lake Sanaruis $2 \mathrm{~m}$. The lake area is $1.2 \mathrm{~km}^{2}$, and the volume is 2.4 million $\mathrm{m}^{3}$. There are three main upstream rivers flowing into the lake. Lake Sanaru is a brackish tidal lake, although it is located far from the seashore, and is affected by organic matter and salt water from one $13 \mathrm{~km}$ downstream river which flows backward. There are 2 exits, which flow from the lake;refer to the map in Figure 1.

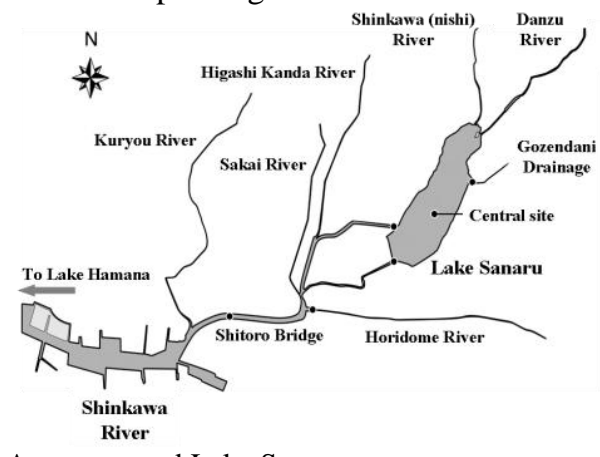

Figure 1.A map around Lake Sanaru 
With an average depth of just 2 meters, Lake Sanaru is considered to be in an aerobic condition on the lake bottom. The nutrient release from sediment is not thought to be very large. As a characteristic of a brackish lake, the lake level due to tides has $\pm 30 \sim 40 \mathrm{~cm}$ variations, and the amount of water volume fluctuates by $3.6 \times 10^{5}-5.0 \times 10^{5}$ $\mathrm{m}^{3}$ per day[7]. However, nutrients like soluble phosphorus in the downstream river are almost the same as in the lake and the average concentration from the three upstream rivers. That means the nutrient transfer and water exchange between Lake Sanaru and the downstream river is not so large. So the main pollution load contributing to the amount of nutrients comes from the upstream rivers. In addition to the weak selfpurification water environment, once the pollution flows into the lake, it can promote internal production, like the abnormal growth of phytoplankton. All of these conditions are not conducive to water purification in Lake Sanaru.

\subsubsection{Analysis of pollution origin}

The catchment zone of Lake Sanaru is higher on the north side than that the south, and the area of the upstream rivers region is $17.67 \mathrm{~km}^{2}$. Farmland area covers only $14 \%$ of that area. After the comprehensivesewerage program was completed in the lake region, the foul sewer coverage rate increased from $77 \%$ in 2001 to $93 \%$ in 2012.It was found that there was a rough correlation between the COD in the lake and the sewer coverage in the upstream region of Lake Sanaru (Figure2).With the increase of foul sewer coverage rate, both total COD and Sol-COD decreased in the lake. Contrastingly, Sol-COD has not decreased at the same level as the Total-COD. The most direct and knowable effect relates to inflow from the river. Although we wantto compare Sol-COD directly in rivers and in the lake, the water quality monitoring data only tested for Total-COD in the three rivers. After working to improve water quality in the rivers for many years, TotalCOD is at 2 to $4 \mathrm{mg} / \mathrm{L}$ in three of the rivers, so they are not so dirty. So we compared the Total-COD in the three upstream rivers and Sol-COD in the lake. It was observed that both of them have a similar fluctuation (Figure3). This fact implies that the main cause of the COD value decrease canbe attributed to the increased coverage of the sewer system.In particular, Sol-COD in the lake is greatly affected by the upstream rivers' pollution load.Therefore, the origins

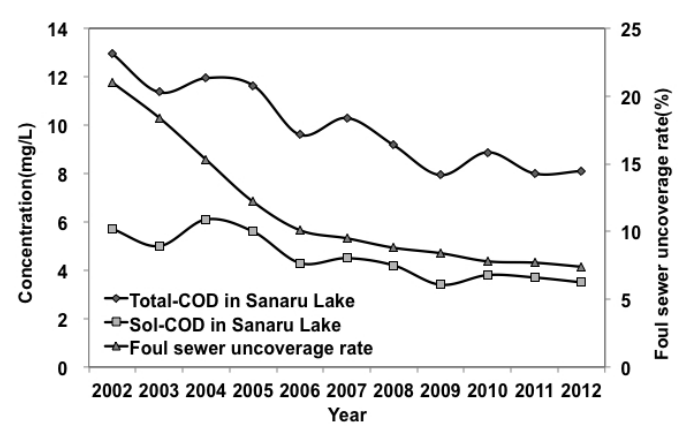

Figure 2. The change of COD and foul sewer coverage rate in the Lake Sanaru region

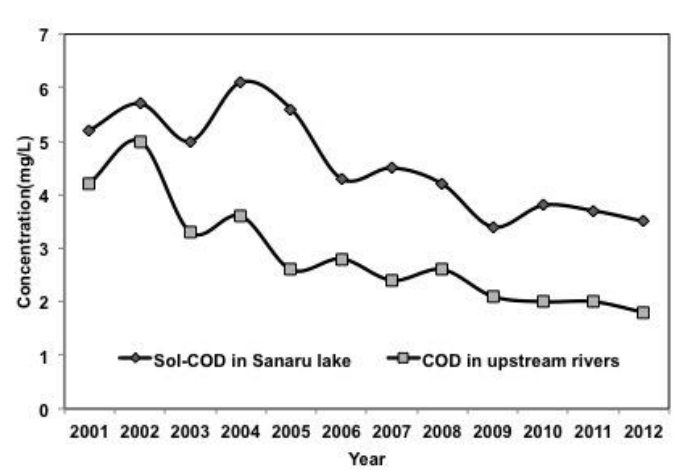

Figure 3.The change of Sol-COD in Lake Sanaru and COD in the upstream rivers

of Sol-COD inthe upstream rivers need to be clarified.We focus on the point resource aboutdomestic sewage.In addition, because Sol-COD in Lake Sanaru is larger than in the upstream rivers by almost $2 \mathrm{mg} / \mathrm{L}$, whether or not the difference between these two numbers comes from the decomposition of algae in Lake Sanaru also needs to be clarified.

Generally, in daily life, the domestic sewage discharge from a kitchen is $17 \%$, the bath is $25 \%$, laundry is $30 \%$, hands and face washing is $8 \%$, and other activities is $10 \%$. Detergent isthe most important pollution contained in domestic sewage. Although the load of domestic wastewater has been reduced due to the development of the sewage system, the pollution load comes from theuncovered sewer area still flowing into the river. These untreated runoffsfoundin the lake can finally be assumed to be difficult-to-decompose organic substances. In order to verify this assumption, we need to check the decomposability of detergent, and to validate whether or not it contributes to the real COD valuein the water.

\subsection{Detergent consumption and emission}

Figure 4 is the percentage figure of detergent consumption in Japan[8]. Detergent used for laundry (liquid and powder) accounts for $47 \%$ of the total detergent consumption. Combined with the next highest seller, kitchen detergent, kitchen and laundry detergent account for $60 \%$ of all detergent consumption. In recent years, people like to use liquid laundry detergent rather than powder laundry detergent, but the total laundry

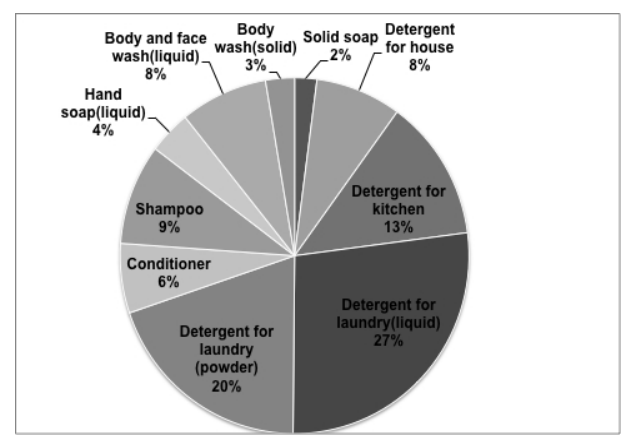

Figure 4. The percentages of detergent consumption in Japan 
detergent market in Japan has remained at almost the same level since 2002 in terms of sales. Also, other detergent consumption has mostly kept steady; only hand-soap sales showed an increase. According to the condition of Japanese detergent consumption, we can choose the most widely used detergent as our detergent solution samples.

Fromformer analysis of the Lake Sanaruregion, we know that the main cause of decrease in COD value is attributable to the increased coverage of sewer systems. The water quality of upstream rivers receiving untreated wastewater from homes would greatly affect the water quality of Sanaru Lake. Thus, in order to estimate the concentration of the detergent in the lake, we need to know how many people are outside of the sewer system and how many detergents are used and flow into the river. Eq. (1) calculates the detergent concentration with public data on the population outside of the sewer system in Sanaru Lake upstream region and the national average of detergent consumption[6,8].

$$
\mathrm{C}=\frac{D c \times P o}{T_{f}}(1)
$$

Where $\mathrm{C}$ is the detergent concentration in the upstream rivers $(\mathrm{g} / \mathrm{L})$. D $c$ is the detergent consumption per head $(\mathrm{g} /$ day $\cdot$ person). Po is the population outside of the foul sewer coverage (person). $\mathrm{T}_{f}$ is the total influx of the upstream rivers $\left(\mathrm{m}^{3} /\right.$ day $)$.

\subsection{Detergent solution in rivers}

\subsubsection{Biodegradation of detergent}

In order to clarify whether the detergent will decompose in river water easily over time, a certain amount of detergent solution was put into river water and kept in a static condition until it reached a steady state. Water quality tests were completed at regular intervals. The experiment was carried out in open air conditions. The detergent solution in the experiment was prepared by the calculation of Eq. (1) for several detergents.Ordinarily, $\mathrm{COD}_{\mathrm{Mn}}$ is used as the indicator for water quality in Japanbecause dichromate, used in Western countries, is itself a heavy metal pollutant[9]. However, owning to the weak oxidation ability of potassium permanganate and the poor additive, TOC is mainly used in our experiment to express the value of dissolved organic matter more exactly[10], especially for the majority of organic substances in detergent that are difficult to decompose.

\subsubsection{Field survey}

Samples were taken twice from six sites along the three upstream rivers (sites A-F, Figure5) on January 10 and January 19, 2012. Two days were sunny. Filled black circles represent sites A-F. The A and B sites are in Gozendani Drainage. The C and D sites are in Danzukawa River. The E and F sites are in Shinkawa River. Samplings were taken by bottle, and then immediately filtered and determined for TOC and anionic surfactants using standard measurement method.

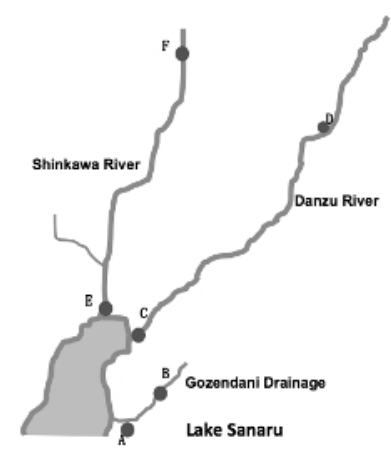

Figure 5.Sampling sites of Lake Sanaru

\section{Results}

\subsection{Detergent consumption}

By the calculation of Eq. (1), we get the detergent concentration from different years. The result is shown in Figure6, as the foul sewer coverage rate increased in recent years, more and more discharge from population was treated. With the type of laundry change, only the liquid laundry detergent increased, other detergentsconcentrations were significantly reduced. The total concentration of the eight detergents in the upstream rivers was $2.7 \mathrm{mg} / \mathrm{L}$ in 2012 (Table 1). Because the detergent and soap included large amounts of organic

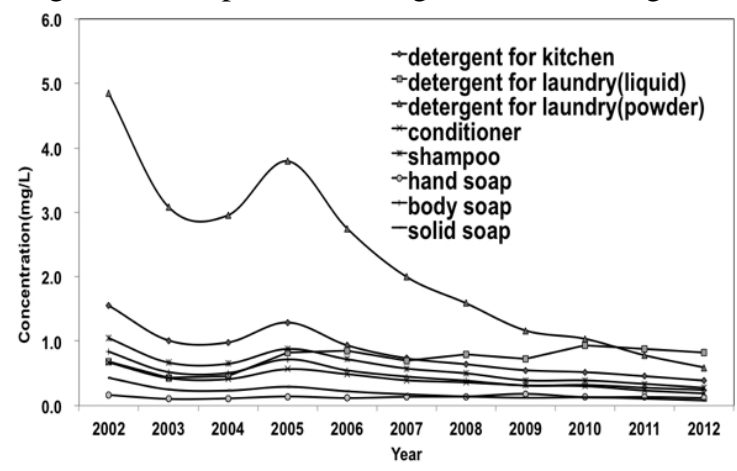

Figure6.Detergent concentrations in the rivers, which are calculated by Eq. (1)

Table 1.Concentration of detergent in solution by calculattion

\begin{tabular}{ll}
\hline Kind of detergent & Concentration $(\mathrm{mg} / \mathrm{L})$ \\
\hline Detergent for kitchen (liquid) & 0.39 \\
\hline Detergent for laundry (liquid) & 0.82 \\
\hline Detergent for laundry (powder) & 0.59 \\
\hline Conditioner & 0.19 \\
\hline Shampoo & 0.28 \\
\hline Hand soap & 0.12 \\
\hline Body soap & 0.24 \\
\hline Solid soap & 0.08 \\
\hline Total & 2.70
\end{tabular}

matter, such as surfactants and fatty acids, in detergent is $40 \%$ percent carbon, TOC of the detergent solution can be estimated to be $1.1 \mathrm{mg} / \mathrm{L}$. When we tested the TOC of the detergent solution that was made according to the 
concentration of Table 1, the measured value was 0.94 $\mathrm{mg} / \mathrm{L}$, which showed a good agreement.

\subsection{Detergent solution in rivers}

\subsubsection{Biodegradation of detergent}

As shown in Table 1, eight kinds of detergent were accurately weighed and dissolved in $1 \mathrm{~L}$ of water. The detergent and water were mixed, and $1 \mathrm{ml}$ of the resulting detergent solution was dissolved in $1 \mathrm{~L}$ of river water and $1 \mathrm{~L}$ water. For a blank test, $1 \mathrm{~L}$ river water was used. These three solutions were kept in a static condition until they reached a steady state; TOC of the three solutions was tested every 12 hours. The results are shown in Figure 7. River water was taken from the upper reaches of Danzukawa River and the total TOC was $6.08 \mathrm{mg} / \mathrm{L}$. TOC of $2.7 \mathrm{mg} / \mathrm{L}$ detergent solution is $0.94 \mathrm{mg} / \mathrm{L}$. For the detergent solution added to the river water, total TOC was $6.85 \mathrm{mg} / \mathrm{L}$. A small part of detergent may have decomposed immediately after addition to the river water. At first, the detergent concentration decreased quickly. After three days, nearly the same value remained. The detergent did not decompose completely. There was 0.32 $\mathrm{mg} / \mathrm{L}$ left. This part of the detergent would eventually flow into the lake.

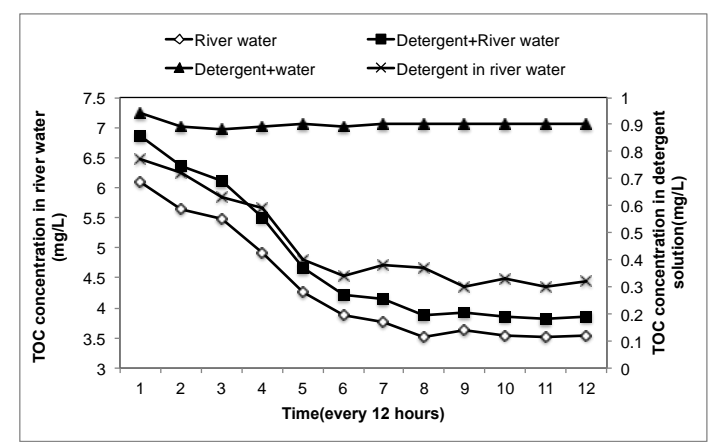

Figure 7.The variation ofdetergent concentration

\subsubsection{Field survey}

The values of TOC, $\mathrm{COD}_{\mathrm{Mn}}$, nitrogen and surfactants in each site were shown in Table 2. For all water samples, values in the downstream sites $\mathrm{A}$ and $\mathrm{E}$ were larger than in the upstream sites B and F. Along with the river flow, more pollution substances flow into the river. However, values in the Danzukawa River at the D site were higher than at the $\mathrm{C}$ site, because the $\mathrm{D}$ site samples were taken in an irrigation channel, not in a natural river. The nitrogen pollution is serious in Shinkawa(nishi)River. There is a positive correlation between TOC and the anionic surfactant concentration (Figure 8). Therefore, detergents strongly affect TOC in Lake Sanaru upstream rivers. We calculated the average TOC in the three rivers, and then obtained a value of $1.2 \mathrm{mg} / \mathrm{L}$, which was almost

Table 2. Test results in 3 rivers $(\mathrm{mg} / \mathrm{L})$

\begin{tabular}{cccccc}
\hline \multicolumn{5}{c}{ SiteTOCSurfactantCOD $\mathrm{Mn} \mathrm{NO}^{2-} \mathrm{NO}^{3-}$} \\
\hline A & 1.1 & 0.10 & 3.5 & 0.02 & 8.3 \\
\hline B & 0.2 & 0.05 & 3.5 & 0 & 8.5
\end{tabular}

\begin{tabular}{|c|c|c|c|c|c|}
\hline $\mathrm{C}$ & 1.7 & 0.15 & 3.5 & 0.02 & \\
\hline D & 3.5 & 0.45 & 5.0 & 0.35 & $\overline{14.0}$ \\
\hline E & 0.9 & 0.10 & 3.0 & 0 & 20.0 \\
\hline $\mathrm{F}$ & 0.1 & 0.05 & 3.0 & 0 & 20.0 \\
\hline \multicolumn{6}{|c|}{ (First time) } \\
\hline \multicolumn{6}{|c|}{ SiteTOCSurfactantCOD ${ }_{\mathrm{Mn}} \mathrm{NO}^{2-} \mathrm{NO}^{3}$} \\
\hline A & 0.8 & 0.25 & 2.5 & 0.02 & 7.3 \\
\hline B & 0.1 & 0.10 & 2.5 & 0 & 7.5 \\
\hline $\mathrm{C}$ & 1.2 & 0.15 & 3.5 & 0.03 & 7.2 \\
\hline $\mathrm{D}$ & 5.3 & 0.50 & 5.5 & 0.70 & 13.0 \\
\hline $\mathrm{E}$ & 0.5 & 0.10 & 2.5 & 0 & 25.0 \\
\hline F & 0.0 & 0.05 & 2.0 & 0 & 25.0 \\
\hline
\end{tabular}

the same as the experiment result. The detailed calculated course is shown in Table 3. The value of TOC was the average value of two tests in the downstream sites.

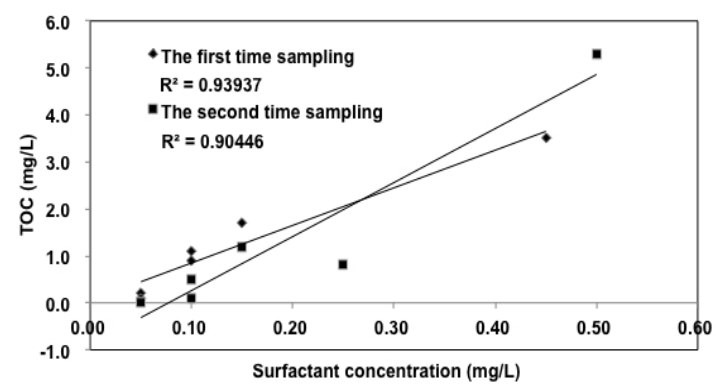

Figure 8 Relationship with TOC and surfactant concentration in the upstream rivers

Table 3. Flow rate and TOC in the three rivers

\begin{tabular}{lcc}
\hline \multicolumn{1}{c}{ River } & $\begin{array}{c}\text { Average annual } \\
\text { flow }\left(\mathrm{m}^{3} / \mathrm{s}\right)\end{array}$ & TOC $(\mathrm{mg} / \mathrm{L})$ \\
\hline Gozendani Drainage & 0.01 & 1.0 \\
\hline Danzu River & 0.29 & 1.5 \\
\hline Shinkawa River & 0.19 & 0.7 \\
\hline Average TOC $=\frac{0.01 \times 1.0}{0.49}+\frac{0.29 \times 1.5}{0.49}+\frac{0.19 \times 0.7}{0.49}=1.2$
\end{tabular}

\section{Discussion}

\subsection{Compare the result}

In our research, we obtained three TOC values through different methods (Table 4). In the first method, the TOC value was estimated by the detergent concentration that was calculated by Eq.(1), and the result of TOC was $1.1 \mathrm{mg} / \mathrm{L}$. In the second method, we weighted eight kinds of detergent and diluted them to the concentrations that were calculated by Eq.(1) for the needed detergent solution, and its TOC was $0.94 \mathrm{mg} / \mathrm{L}$. In the third method, according to the calculation with flow rate and field survey of TOC values in the samples from three rivers, average TOC concentration was determined to be 1.2 $\mathrm{mg} / \mathrm{L}$. We compared the results of the three methods and

Table 4. TOC results compared in different way $(\mathrm{mg} / \mathrm{L})$

\begin{tabular}{ccc}
\hline $\begin{array}{c}\text { TOC by estimate from } \\
\text { detergent concentration }\end{array}$ & $\begin{array}{c}\text { TOC test in } \\
\text { detergent } \\
\text { solution }\end{array}$ & $\begin{array}{c}\text { TOC sampling test and } \\
\text { calculation in all rivers }\end{array}$ \\
\hline 1.1 & 0.94 & 1.2 \\
\hline
\end{tabular}


all of them were roughly the same. The result suggested that TOC in the upstream rivers mostly comes from detergent.

\subsection{The origin of other Sol-COD}

We have known that there is a similar fluctuation change of Sol-COD in the rivers and the lake, but they have about a $2 \mathrm{mg} / \mathrm{L}$ difference between them. In order to prove the origin of this part, water from Lake Sanaru was treated with $40 \mathrm{kHz}$ ultrasonic waves to disrupt algae cells. The color of the lake water (pale yellow) did not change much after the use of the ultrasonic wave machine, but the Sol-COD value changed from $4 \mathrm{mg} / \mathrm{L}$ to $6 \mathrm{mg} / \mathrm{L}$. Thus, after applying the ultrasonic wave to the water, the Sol-COD components of about $2 \mathrm{mg} / \mathrm{L}$ eluted from the carcasses of the algae (Table 5). This is the part of Lake Sanaru which internally generated content.

Table 5.COD internally generated $(\mathrm{mg} / \mathrm{L})$

\begin{tabular}{ll}
\hline $\begin{array}{l}\text { From the difference between } \\
\text { rivers and lake }\end{array}$ & $\begin{array}{l}\text { From algae carcass in the } \\
\text { experiment }\end{array}$ \\
\hline $1 \sim 2$ & $1 \sim 2$ \\
\hline
\end{tabular}

\section{Conclusions}

In this study, we clarified the origin of Soluble COD in Lake Sanaru.In the upstream rivers, there is a positive correlation between the anionic surfactant concentration and the TOC in the water. In addition, the TOC of detergent solution was the same as the actual measurement in the upstream rivers. This indicated that the origin of Sol-COD in Lake Sanaru came from detergent in domestic sewage. The same approachcan also be applied to other lakes'governance and estimationof pollution concentration especially detergents.Although we found good agreement between the experiment and field survey, twice samplings were obtained on sunny days; the nonpoint pollution effect from farmland and streets didn't show clearly in this research. Therefore, future studyshould be done on a rainy day. In the future, the way to reduce Sol-COD is improve the sewer connection rate in the Lake Sanaru region. If the sewer connection rate is completely improved, organic matter concentration in the river could be greatly reduced. In addition, with the sewer connection completed, the phosphorus in the upstream rivers also will be greatly reduced, so that phytoplankton amount in the lake would also be inhibited. Thus, Total-COD in Lake Sanaru could possibly be below $5 \mathrm{mg} / \mathrm{L}$. But one problem to which attention must be paid is that the total river flux will also be decreased, owning to a sewer connection rate increase. This may influence the water exchange as well as the phytoplankton growth and fish catch. Therefore, it is necessary to discuss whether or not the value of Total-COD in Lake Sanaru can achieve expectations. Lake Sanaru is a brackish tidal lake affected by organic matter from one downstream river which flows backward. It can be assumed that the tidal water exchange between Lake Sanaru and Lake Hamana must control or affect internal generation by being mixed in the dilution process in the lake and downstream Shinkawa River. Attention needs to be paid to this part of the research in the future.

\section{References}

1. H. Melcer, P. L. Dold, R. M. Jones,C. M. Bye, I.Takacs, H. D.Stensel, A. Warren Wilson, Paul Sun, Scott BuryMethods for Wastewater Characterization in Activated Sludge Modeling(WERF, 2003)

2. C. Köhler, COD fraction dynamics: Respirometric analysis \&modeling sewer processes (Diplomarbeit to reach the degree of a Diplomingenieur of Water Management Academic year 2007-2008)

3. F. Raposo, M.A. de la Rubia, R. Borja, M. Alaiz, J. Talanta76, 448-453 (2008)

4. N. H. Tran, H. H. Ngo, T. Urase, K. Y.H. Gin, J. Bior Tech193, 523-533 (2015).

5. Hamamstsu, Shizuoka Prefecture public waters water quality measurement results (2001-2014). (http://www.hamamatsukankyo.jp/suishitsu/district/naka_situation.htm)

6. K. Otsuka, K. Fujita, Y. Isono, and M. Mizuochi, Governance for Water Environment Conservation: Implications from Japanese Experiences(2005)

7. K. Yasuda, M. Iga and S.Sawamoto,J. The School of Marine Science and Technology, Vol.8,No.1, 1325(2010)

8. Japan Soap and Detergent Association statistics (2002-2014) (http://jsda.org/w/index.html)

9. S. Araki, M. Numata, O. Wada, Kankyokagakuziten (A Dictionary of Environmental Sciences)Kagakudozin, Tokyo (1985)

10. G. Visco, L. Campanella, V. Nobili, J. Microc79, 185-191(2005) 